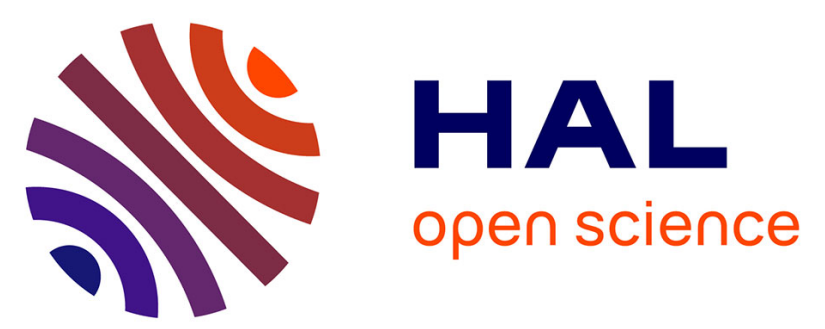

\title{
Identification of marine key areas across the Caribbean to ensure the conservation of the critically endangered hawksbill turtle
}

\author{
Manon Nivière, Philippine Chambault, Thierry Pérez, Denis Etienne, Marc
} Bonola, Jordan Martin, Cyrille Barnerias, Fabien Védie, Julien Mailles, Émilie Dumont-Dayot, et al.

\section{To cite this version:}

Manon Nivière, Philippine Chambault, Thierry Pérez, Denis Etienne, Marc Bonola, et al.. Identification of marine key areas across the Caribbean to ensure the conservation of the critically endangered hawksbill turtle. Biological Conservation, 2018, 223, pp.170 - 180. 10.1016/j.biocon.2018.05.002 . hal-01929768

\section{HAL Id: hal-01929768 \\ https://hal-amu.archives-ouvertes.fr/hal-01929768}

Submitted on 21 Nov 2018

HAL is a multi-disciplinary open access archive for the deposit and dissemination of scientific research documents, whether they are published or not. The documents may come from teaching and research institutions in France or abroad, or from public or private research centers.
L'archive ouverte pluridisciplinaire HAL, est destinée au dépôt et à la diffusion de documents scientifiques de niveau recherche, publiés ou non, émanant des établissements d'enseignement et de recherche français ou étrangers, des laboratoires publics ou privés. 
archives-ouvertes

\title{
Identification of marine key areas across the Caribbean to ensure the conservation of the critically endangered hawksbill turtle
}

\author{
Manon Nivière, Philippine Chambault, Thierry Pérez, Denis Etienne, Marc
} Bonola, Jordan Martin, Cyrille Barnerias, Fabien Védie, Julien Mailles, Émilie Dumont-Dayot, et al.

\section{To cite this version:}

Manon Nivière, Philippine Chambault, Thierry Pérez, Denis Etienne, Marc Bonola, et al.. Identification of marine key areas across the Caribbean to ensure the conservation of the critically endangered hawksbill turtle. Biological Conservation, Elsevier, 2018, 223, pp.170 - 180. $<10.1016 /$ j.biocon.2018.05.002>. <hal-01929768>

\section{HAL Id: hal-01929768 \\ https://hal-amu.archives-ouvertes.fr/hal-01929768}

Submitted on 21 Nov 2018

HAL is a multi-disciplinary open access archive for the deposit and dissemination of scientific research documents, whether they are published or not. The documents may come from teaching and research institutions in France or abroad, or from public or private research centers.
L'archive ouverte pluridisciplinaire HAL, est destinée au dépôt et à la diffusion de documents scientifiques de niveau recherche, publiés ou non, émanant des établissements d'enseignement et de recherche français ou étrangers, des laboratoires publics ou privés. 


\title{
Identification of marine key areas across the Caribbean to ensure the conservation of the critically endangered hawksbill turtle
}

\author{
Manon Nivière $^{\mathrm{a}, *}$, Philippine Chambault ${ }^{\mathrm{a}}$, Thierry Pérez ${ }^{\mathrm{b}}$, Denis Etienne ${ }^{\mathrm{c}}$, Marc Bonola ${ }^{\mathrm{a}}$, \\ Jordan Martin $^{\mathrm{a}}$, Cyrille Barnérias ${ }^{\mathrm{c}}$, Fabien Védie ${ }^{\mathrm{c}}$, Julien Mailles ${ }^{\mathrm{c}}$, Émilie Dumont-Dayot ${ }^{\mathrm{d}}$, \\ Julie Gresser ${ }^{\mathrm{e}}$, Gaëlle Hiélard ${ }^{\mathrm{e}}$, Sidney Régis ${ }^{\mathrm{a}}$, Nicolas Lecerf ${ }^{\mathrm{a}}$, Laurent Thieulle ${ }^{\mathrm{a}}$, Matthieu Duru ${ }^{\mathrm{a}}$, \\ Fabien Lefebvre $^{\mathrm{a}}$, Guillaume Milet ${ }^{\mathrm{a}}$, Blandine Guillemot ${ }^{\mathrm{f}}$, Bernard Bildan ${ }^{\mathrm{g}}$, \\ Benjamin de Montgolfier ${ }^{\mathrm{h}}$, Abdelwahab Benhalilou ${ }^{\mathrm{i}}$, Céline Murgale ${ }^{\mathrm{i}}$, Thomas Maillet ${ }^{\mathrm{i}}$, \\ Patrick Queneherve ${ }^{\mathrm{j}}$, Thierry Woignier ${ }^{\mathrm{k}}$, Morjane Safi ${ }^{\mathrm{a}}$, Yvon Le Maho ${ }^{\mathrm{a}}$, Odile Petit ${ }^{\mathrm{t}}$, \\ Damien Chevallier ${ }^{\mathrm{a}, *}$
}

${ }^{a}$ Université de Strasbourg, CNRS-IPHC UMR 7178, 23 rue Becquerel, 67087 Strasbourg Cedex 2, France

${ }^{\mathrm{b}}$ Institut Méditerranéen de Biodiversité et d'Ecologie marine et continentale, CNRS-Université Aix-Marseille, IRD-University Avignon, Station Marine d'Endoume, rue de la batterie des lions, 13007 Marseille, France

${ }^{c}$ DEAL Martinique, Pointe de Jaham, BP 7212, 97274 Schoelcher Cedex, France

${ }^{\mathrm{d}}$ Services de Police de l'environnement, 5 rue de la Dorade, Anses à l'Ane, 97229 Trois Ilets, Martinique, France

e Office de l'Eau Martinique, 7 Avenue Condorcet, BP 32, 97201 Fort-de-France, Martinique, France

${ }^{\mathbf{f}}$ Délégation Inter Régionale Outre-mer, Cellule technique Antilles françaises, Chemin de Boyer, Section Boisbert, 97129 Lamentin, Guadeloupe, France

${ }^{g}$ UCPA Saint Pierre, Rue Georges Roger de Fabrique Saint Tours Fond Coré, 97250 Saint Pierre, France

${ }^{\text {h }}$ Aquasearch, ZAC Les Coteaux, 97228 Sainte-Luce, Martinique

${ }^{i}$ Association POEMM, 73 lot papayers, Anse a l'âne, 97229 Les Trois Ilets, Martinique

${ }^{\mathrm{j}}$ IRD Martinique-Caraibe, Campus Agro-Environnemental Caraibe, BP 214, 97285 Le Lamentin Cédex2, Martinique

${ }^{\mathbf{k}}$ Institut Méditerranéen de Biodiversité et d'Ecologie marine et continentale, CNRS-Université d'Aix-Marseille, IRD, University Avignon 13007, Marseille, France

${ }^{1}$ CNRS, Équipe d'Éthologie Cognitive et Sociale, Délégation Alsace, MOY 1000, 23 rue du Loess, 67087 Strasbourg, France

\section{A R T I C L E I N F O}

\section{Keywords:}

Eretmochelys imbricata

Migration

Diving behaviour

Home range

French Antilles

Satellite tracking

\begin{abstract}
A B S T R A C T
Acquisition of data on animal movement when developing management strategies is a common challenge in species conservation, especially when dealing with a critically endangered species as the hawksbill turtle Eretmochelys imbricata. To reach the objective of the 2008 national action plan for Martinique Island (French West Indies), the present paper examines horizontal and vertical movements in juveniles $(n=3)$ and adults life stages (11 females and 2 males) of 16 hawksbill turtles. Our results reveal the strong site fidelity of individuals to their foraging grounds (mean male foraging home range: $89.3 \pm 20.2 \mathrm{~km}^{2}$, mean female foraging home range: $336 \pm 284.7 \mathrm{~km}^{2}$, mean juvenile foraging home range: $157.3 \pm 71.2 \mathrm{~km}^{2}$ ) and to the females' inter-nesting areas (mean home range: $284.2 \pm 523.7 \mathrm{~km}^{2}$ ). A spatial foraging overlap occurred between juveniles and males as they shared $41 \%$ of their $95 \%$ kernel foraging habitat. The turtles performed mainly long and shallow dives within the first $20 \mathrm{~m}$ deep around Martinique Island, occupying shallow waters close to shore. The migratory routes of the adult females revealed regional connectivity between the Caribbean islands, crossing 31 exclusive economic zones and international waters, and featuring distinct foraging grounds. This finding reinforces the significance of a cooperative network at the Caribbean scale to ensure the efficient conservation of this critically endangered species.
\end{abstract}

\section{Introduction}

Acquisition of data on animal movement when developing management strategies is a common challenge in species conservation. The field of movement ecology describes animal movement according to its attributes: the type of movement, i.e. nomadism, migration and residency, and the characteristics of the movement, i.e. migration distance, stopovers and the size and shape of the home range (Allen and

\footnotetext{
* Corresponding authors.

E-mail addresses: manon.niviere@gmail.com (M. Nivière), damien.chevallier@iphc.cnrs.fr (D. Chevallier).
} 
Singh, 2016). The recent growth of this field of research has highlighted supplementary challenges as obtaining data on available resources linking with position data, quantifying metabolic cost of movement or manages large spatio-temporal datasets (Cagnacci et al., 2010, Hays et al., 2016). The wide distribution of marine migratory species such as marine mammals, seabirds and sea turtles makes their protection especially difficult as it's require maintaining connectivity, combining logistical and political issues (Runge et al., 2014; Allen and Singh, 2016). Among sea turtles, the hawksbill turtle Eretmochelys imbricata is widely distributed across the tropical and subtropical waters of at least 108 countries (Mortimer and Donnelly, 2008). The unsustainable exploitation of hawksbill turtles' shell and eggs has contributed to a severe decline of their populations worldwide. The majority of this trade ceased after the listing of the hawksbill turtle in Annex 1 of the CITES Convention in 1977 and its recognition as a critically endangered species on the International Union for Conservation of Nature Red List (IUCN) in 1996 (Meylan, 1999). However, trade remains legal in CITES non-signatory countries and illegal trade persist. Hawksbill turtles are also continuously exposed to bycatch and/or destruction of their habitats both at sea and on land. Knowledge on diving behavior of this species and its distribution at-sea is crucial for ensuring its conservation at the global scale (Hamann et al., 2010).

To implement targeted and flexible management actions, it is essential to delineate the high-use areas, both spatially and temporally. Satellite telemetry has facilitated the identification of residence areas, where hawksbill turtles are particularly vulnerable to potential threats dues to the aggregative behavior they display there (Rees et al., 2016). For both juvenile and adult stages, hawksbill turtles usually establish restricted foraging home ranges with small core use area for long period (Limpus, 1992; Blumenthal et al., 2009b; Pilcher et al., 2014). Juvenile foraging habitats are generally associated with the presence of coral reefs (Cuevas et al., 2008; Blumenthal et al., 2009b; Rincon-Diaz et al., 2011), and does not seems to differ with habitat characteristics of adults foraging habitats. It has been reported that juveniles foraging home range could share their foraging habitats with adults (green turtle Chelonia mydas and loggerhead turtle Caretta caretta: Meylan, 2011; hawksbill turtle Eretmochelys imbricata: Diez and Van Dam, 2002), reinforcing the importance of restricted site for this species. Males might breed every year and therefore could stay close to the nesting area (Ferreira et al., 2018). On the contrary, females undertake long migration between their nesting beaches and their foraging grounds (Van Dam et al., 2008; Cuevas et al., 2008; Hart et al., 2012). Some routes connecting hawksbill Caribbean habitats have thus been identified, providing a pattern of a migratory dichotomy with some turtles remaining close to the nesting beach whereas others migrated far away towards Nicaragua and Honduras (Cuevas et al., 2008; Hawkes et al., 2012), but to date no information is available in the French West Indies, where this species is commonly seen. Among the research priorities highlighted to date, evaluate connectivity between the various nesting sites and foraging areas is a key necessity to evaluate population-level impacts of anthropogenic threats (Hamann et al., 2010).

Satellite transmitters not only inform about the surface movements of this species, but can also reveal their diving behavior, providing information on their distribution in the water column which may improve the management of anthropogenic pressures in key areas, i.e. inter-nesting and foraging habitats. The different dive patterns exhibited by sea turtles could vary according to different purposes, i.e. mating, foraging, resting or travelling (Blanco et al., 2013; Gaos et al., 2012a). Indeed, the amount of activity seems to fluctuate among dives and influence dive duration (Okuyama et al., 2012). Storch (2003) has suggested that long dives during the inter-nesting period could be associated with a resting activity. In the East Pacific Ocean, it has also been suggested that hawksbill turtles concentrate their activities in shallow waters $(<20 \mathrm{~m}$ ), regardless of the life stage (Gaos et al., 2012a). This behavior could be associated with the dietary preference of hawksbill turtles for sponges and macroalgae, which are found in their highest densities in shallow waters (León and Bjorndal, 2002; Meylan, 1999).

Although several studies have focused on the satellite tracking of hawksbill turtles across the Caribbean region (Blumenthal et al., 2009a; Meylan, 1999; Van Dam and Diez, 1998), the knowledge of their at-sea ecology and their dive behavior is poorly understood, especially in the French West Indies (Guadeloupe and Martinique Islands). Despite the recognition of these two islands as important nesting sites for hawksbill turtles (Meylan, 1999), no studies of turtle movements have been conducted there to date. Severe anthropogenic pressures and the alarming situation of hawksbill populations in these islands led to the adoption of prefectural decrees for the protection of sea turtles and their eggs in Guadeloupe and Martinique (1991 and 1993, respectively), reinforced by a ministerial decree in 2015 including protection of their habitats. In 2005, the French Ministry for Ecology, Sustainable Development and Energy strengthen these measures by making the hawksbill turtle a priority species of the restoration plan for sea turtles of the French West Indies (Chevalier, 2006). This program was supported by a Sea Turtle National Action Plan organizing conservation actions for sea turtles' restauration in Martinique for the 2008-2017 period. One of the main objectives of this plan was to study the distribution and diving behavior of adult and juvenile hawksbill turtles in Martinique waters.

To reach this objective, satellite tracking was used to follow horizontal and vertical movements of 16 hawksbill turtles at two different life stages, i.e. juvenile and adult, for both sexes. This study aimed to (1) assess the home range of hawksbill turtles to their inter-nesting (females) and foraging grounds (females, males, juveniles), (2) investigate potential overlap between juveniles and males foraging home ranges (3) identify the migratory routes and foraging grounds used across the Caribbean and (4) assess the diving patterns of this species at two life stages, juveniles and adults, and for both sexes. The results of this study could enrich the sea turtle Action Plan of the French West Indies and would support the development of efficient conservation measures across the Caribbean.

\section{Materials and methods}

\subsection{Ethics statements}

This study meets the legal requirements of the countries in which the work was carried out and follows all institutional guidelines. The protocol was approved by the "Conseil National de la Protection de la Nature" (CNPN, http://www.conservation-nature.fr/acteurs2.php?id= 11), and the French Ministry for Ecology, Sustainable Development and Energy (permit number: 2013154-0037), which acts as an ethics committee in Martinique. After the evaluation of the project by the CNPN, fieldwork was carried out in strict accordance with the recommendations of the Police Prefecture of Martinique in order to minimize the disturbance of animals.

\subsection{Capture and tag deployment}

\subsubsection{Juveniles and males}

Three juveniles (\#130775, \#131353, \#130778) and two adult males (\#130772, \#130777), identified thanks to the size and the development of sexual characteristics like protruding tails, were captured between $09 / 23 / 2013$ and $09 / 28 / 2013$ in northern Martinique (Prêcheur, $14^{\circ} 79 \mathrm{~N},-61^{\circ} 22 \mathrm{~W}$ ) - see Fig. 1 , site 1 . The turtles were captured at depths ranging from 2 to $15 \mathrm{~m}$. The capture of each turtle was performed by up to three freedivers, preferably when the turtle was static, i.e. resting or feeding at the bottom. When the animal was head down, the freediver silently dived close to the head of the turtle and when vertical to the animal, grasped the nuchal shell and pygales plate. The freediver then positioned the turtle against his chest with the hind flippers against his breastplate and rose to the surface. A second diver 


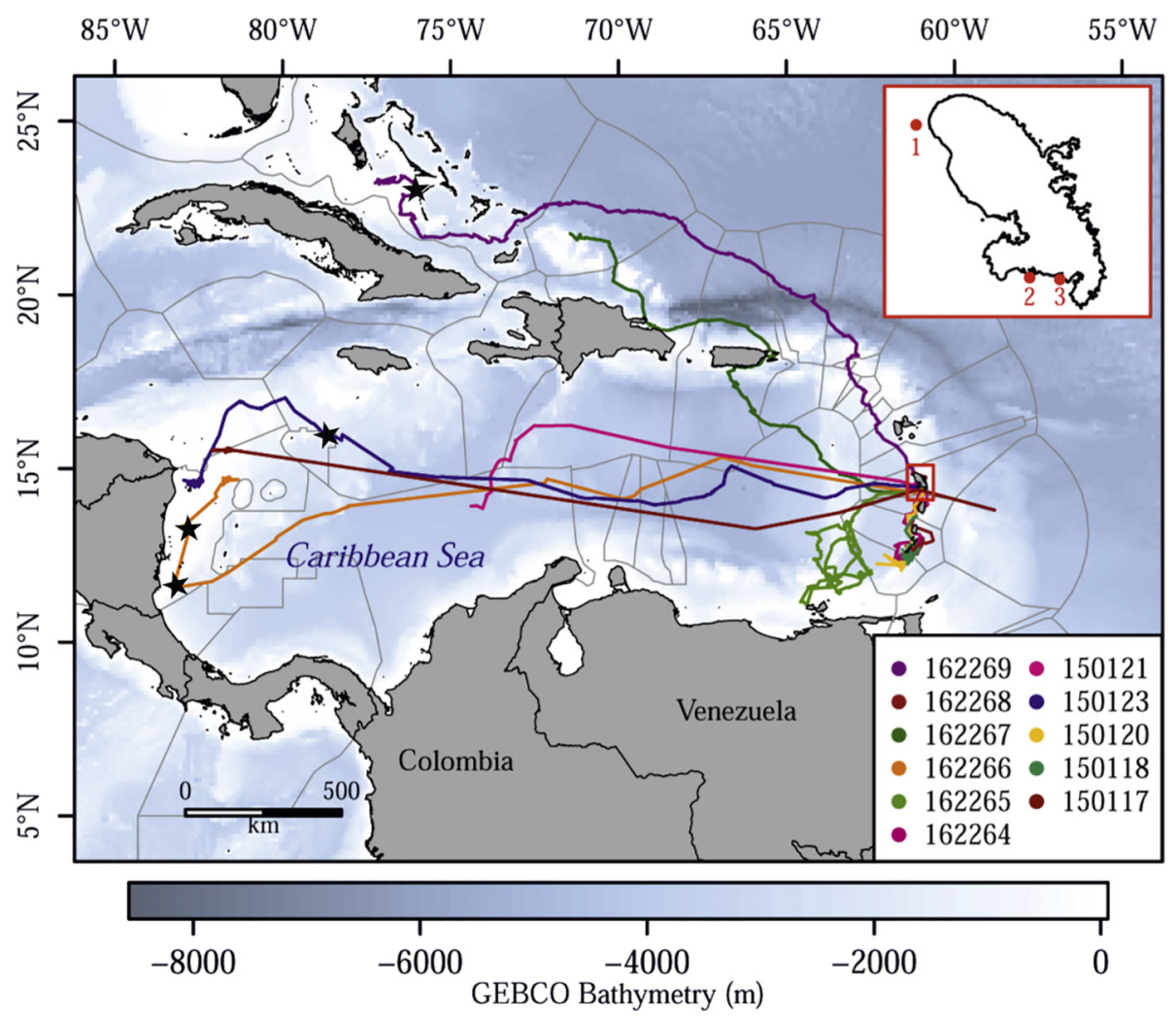

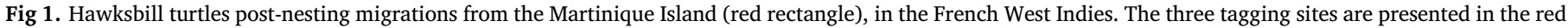
rectangle on the up right of the figure, namely: Prêcheur (1), Diamant (2) and Saint-Luce sites (3).

Table 1

Summary of tags implemented in $2013(n=5), 2015(n=6)$ and $2016(n=6)$.

\begin{tabular}{|c|c|c|c|c|c|c|c|c|}
\hline Tag type & Year & $\mathrm{n}$ & Stage & Sex & GPS & Dive depth (m) & Dive duration (min) & Temperature $\left({ }^{\circ} \mathrm{C}\right)$ \\
\hline \multirow[t]{2}{*}{ SPLASH } & 2013 & 3 & Juveniles & - & Yes & $10-250$ & $30 s-60$ & $20-32$ \\
\hline & & 2 & Adults & Males & & & & \\
\hline SPLASH & 2015 & 1 & Adult & Female & Yes & $0-250$ & $1-60$ & $0-33$ \\
\hline SPOT & & 5 & Adults & Females & No & - & - & $10-60$ \\
\hline SPOT & 2016 & 6 & Adults & Females & No & - & - & $10-60$ \\
\hline
\end{tabular}

held the foreflippers and helped to lift the turtle on to the deck of the boat for measurements and tagging. Each turtle was placed in a pen and standard morphometric data were then recorded, i.e. curved carapace length (CCL) and curved carapace width (CCW). A Passive Integrated Transponder (PIT) was inserted into the right triceps of each individual. The five turtles ( 3 juveniles and 2 males) were finally equipped with Argos-Fastloc GPS tags (10-F-296B, Wildlife Computers Redmond, WA, USA), then released.

\subsubsection{Adult females}

In August 2015, adult females from Diamant beach $\left(14^{\circ} 47 \mathrm{~N}\right.$, $-61.03 \mathrm{~W})$ and Sainte-Luce beaches $\left(14^{\circ} 47 \mathrm{~N},-60^{\circ} 96 \mathrm{~W}\right)$ in southern Martinique were equipped with satellite tags while laying their eggs (Fig. 1, sites 2 and 3). In August 2016, two more nesting females were equipped in northern Martinique (Prêcheur site), and four others in southern Martinique (Diamant and Saint Luce beaches). Except one of the Prêcheur site beach where less to 25 activity tracks are usually recorded, between 25 and 100 activity tracks are usually recorded on Diamant and Sainte-Luce beaches. A total of 11 females were fitted with Argos SPOT tag (293A, Wildlife Computers Redmond, WA, USA), and one female (\#150123) with an Argos-Fastloc GPS tag (10-F-296A; Wildlife Computers Redmond, WA, USA).

\subsection{Data collected from the tags}

To provide optimum location accuracy and increase the number of positions available in order to counterbalance errors caused by the close vicinity of the shore, the Argos GPS tags $(n=6)$ were set up to simultaneously record Argos and GPS locations (Costa et al., 2010; Rutz and Hays, 2009). The GPS sampling interval was set to $4 \mathrm{~h}$ but likely due to this limited sampling interval, no GPS locations was recorded.

The tags provided diving data binned as 4-h period histograms, i.e. maximum dive depth, maximum dive duration and temperature. The SPLASH (Argos-Fastloc) tags deployed in 2013 were set up to collect maximum dive depths every $10 \mathrm{~m}$ from 10 to $100 \mathrm{~m}$, and then every $50 \mathrm{~m}$ from 100 to $250 \mathrm{~m}$ (Table 1). Maximum dive durations were stored from $30 \mathrm{~s}$ to $1 \mathrm{~min}$, then every minute from 1 to $5 \mathrm{~min}$, every $5 \mathrm{~min}$ from 5 to $10 \mathrm{~min}$, and finally every $10 \mathrm{~min}$ from 10 to $60 \mathrm{~min}$. Temperatures were recorded during dives at one-degree intervals from 20 to $32^{\circ} \mathrm{C}$

The SPLASH (Argos-Fastloc) tag deployed in 2015 was set up to collect maximum depths every $5 \mathrm{~m}$ from 0 to $20 \mathrm{~m}$, then every $10 \mathrm{~m}$ from 20 to $100 \mathrm{~m}$, and finally every $50 \mathrm{~m}$ from 100 to $250 \mathrm{~m}$ (Table 1). Maximum dive durations were stored every minute from 1 to $5 \mathrm{~min}$, every $5 \mathrm{~min}$ from 5 to $30 \mathrm{~min}$, and finally every $10 \mathrm{~min}$ from 30 to $60 \mathrm{~min}$. Temperatures were recorded at one-degree intervals from 0 to $33^{\circ} \mathrm{C}$. 
The SPOT tags deployed in 2015 and 2016 were programmed to provide data for horizontal behavior by recording Argos locations and temperatures every $5{ }^{\circ} \mathrm{C}$ from 10 to $20^{\circ} \mathrm{C}$, every $2{ }^{\circ} \mathrm{C}$ from 20 to $30^{\circ} \mathrm{C}$, and finally at $33^{\circ} \mathrm{C}$ and $60^{\circ} \mathrm{C}$ (Table 1 ).

\subsection{Data pre-filtering}

Data were downloaded daily via Argos Message Retriever (WC-DAP, Wildlife Computers Data Analysis Programs). CLS (Collecte Localisation Satellites, Toulouse, France) enhanced Argos position estimates by applying Kalman-filtering algorithm to account for Argos errors. The altimetry product provided by the Hydrographic and Oceanographic Service of the French Navy (SHOM) at a $25 \mathrm{~m}^{2}$ resolution was used to identify and discard erroneous locations on land. Class Z (i.e. insufficiently accurate) Argos locations and any locations associated with a travel speed of over $5 \mathrm{~km} . \mathrm{h}^{-1}$ were also discarded (Schofield et al., 2013), resulting in a total of $19.8 \%$ of data being removed. The most of data remaining was class B (87.8\%) but a few were class A $(7.2 \%), 2$ (1.5\%), 1 (1.4\%), $3(1.3 \%)$ and 0 (0.7\%). Individual \#150119 becoming trapped in the mangrove in 2015 , data collected by its tag were not analyzed.

\subsection{Spatial analysis}

All analyses were carried out using R software version 3.3.3 (R Core Team, 2017). The straight-line distance traveled was calculated between the first and the last locations for each female using the trackDistance function from the trip package (Sumner, 2016). The overall distance between two successive locations was calculated for each turtle. The travelling speed was then derived from the overall distance and time elapsed between paired locations. The date of migration departure was determined for each adult female tracked in 2015 and 2016 by performing a spatial query in ArcGIS (Baudouin et al., 2015; Chambault et al., 2015; Chambault et al., 2016a \& b). Potential foraging grounds were identified by analyzing the post-nesting migratory routes of the 11 females, measuring the proportion of time the turtles spent in each grid cell (resolution of $33.4 \times 33.4 \mathrm{~km}$ ) using the tripGrid function from the trip package (Sumner, 2016). Areas where a female remained at least three consecutive days were considered as a stopover. First location recorded in the potential foraging ground identified was consider as the end of the migration. Based on dates of departure and arrival of migration, the data sets for the females were then split into three groups according to the phase, namely the inter-nesting, migration and final foraging.

\subsection{Kernel analysis}

In order to display the residency patterns of juveniles, males and females during the inter-nesting season and at foraging grounds, home ranges were estimated using the kernel density distributions (KDE) based on the Argos positions (Worton, 1989), as no GPS data was recorded by the tags. To minimize autocorrelation in spatial analysis, the median daily locations were calculated for each turtle (Schofield et al., 2013) and implemented in the kernelUD function from the adehabitatHR package (Calenge, 2006). Kernel densities were estimated for the juveniles $(n=3)$, the males $(n=2)$ and the females at their inter-nesting $(n=9)$ and potential foraging habitats $(n=8)$. The minimum smoothing parameter was used to prevent fragmentation of home range estimates, as suggested by Kie (2013). The 50\% and the $95 \%$ kernel contours were used to identify the core use area and the broad home range, respectively. The overlap between the home ranges of juveniles and males was measured by extracting the kernel contours using the getverticesHR function from the adehabitatHR package (Calenge, 2006). The intersection between the extracted contours was then estimated using the gIntersection function from the rgeos package (Bivand and Rundel, 2017).

\subsection{Dive analysis}

The dive data for females were split into three groups according to the habitat, namely inter-nesting, migration and potential foraging grounds, then the dive data collected for females during the internesting period $(n=1)$ were compared to those of the juveniles $(n=3)$ and the males $(n=2)$ to enable a comparison of the diving behavior among the resident turtles.

\subsection{Statistical analysis}

All statistical analyses were carried out using $\mathrm{R}$ software version 3.3.3 (R Core Team, 2017). Variance normality and homogeneity were verified using a Shapiro-Wilcoxon test. Non-parametric Kruskal-Wallis or Wilcoxon tests were used to compare dive behavior between juveniles, males and females and also between individuals within each group. Values are shown as means $\pm \mathrm{SD}$.

\section{Results}

A total of seventeen hawksbill turtles were satellite tagged in 2013 $(n=5), 2015(n=6)$ and $2016(n=6)$ at three different sites on Martinique Island, French West Indies (Fig. 1). The close vicinity to the shore and the possible Argos error resulted in $52.7 \%$ of the positions being found on land and removed.

\subsection{Sedentary movements}

The CCL of the three juvenile turtles was an average $51.5 \pm 4.8 \mathrm{~cm}$ (range: $48-57 \mathrm{~cm} ; \quad \# 131353$ vs. \#130775), and CCW was $45.3 \pm 6.2 \mathrm{~cm}$ (range: $41.5-52.5 \mathrm{~cm}$, \#131353 vs. \#130778) - see Table 2. These individuals were tracked for $208 \pm 50 \mathrm{~d}$. The three turtles travel at an average speed of $0.3 \pm 0.1 \mathrm{~km} \cdot \mathrm{h}^{-1}$. All the juveniles occupied a foraging home range (KDE) located north of Martinique, close to the capture site (Fig. 2a). The juveniles' 95\% kernel contour (based on Argos locations only) covered $157.3 \pm 71.2 \mathrm{~km}^{2}$ (range: $83.8-220.0 \mathrm{~km}^{2}$, \#130775 vs. \#130778), and a core area (50\% kernel contour) of $12.2 \pm 4.2 \mathrm{~km}^{2}$ (range: $8.8-21.6 \mathrm{~km}^{2}$, \#131353 vs. \#130778) - Table 2.

The two males were tracked for $148 \mathrm{~d}$ (\#130772) and $359 \mathrm{~d}$ (\#130777), respectively (Table 2). Their mean CCL was $80.4 \pm 7.6 \mathrm{~cm}$, and they were $70 \pm 2.9 \mathrm{~cm}$ wide. They traveled $1089 \pm 718.4 \mathrm{~km}$ at an average speed of $0.3 \pm 0.01 \mathrm{~km} \cdot \mathrm{h}^{-1}$. These two males established a foraging home range close to the capture site, located north of Martinique (Fig. 2b). Both males occupied an average $95 \%$ kernel contour of $89.3 \pm 20.2 \mathrm{~km}^{2}$, with a core area covering $12.9 \pm 1.1 \mathrm{~km}^{2}$ - Table 2 .

Only nine of the twelve equipped females were considered for the analysis during the inter-nesting period, as the remaining two females (\#150117 and \#150118) had begun their migration immediately after tag deployment and the females \#150119 was trapped in the mangrove. These nine individuals were tracked for between one and $27 \mathrm{~d}$ (mean: $14.5 \pm 8.9 \mathrm{~d}$ ) and traveled up to $251 \mathrm{~km}$ (\#150123 vs. $\# 150121$, mean: $65.7 \pm 79.9 \mathrm{~km})$ at an average speed of $0.2 \pm 0.1 \mathrm{~km} \cdot \mathrm{h}^{-1}$ (Table 2). As the number of locations recorded during the inter-nesting season was low, the kernel density could not be estimated for individuals \#150120 $(n=5)$, \#162269 $(n=5)$, \#150123 $(n=3), \# 162266(n=3)$ and \#162267 $(n=2)$. The four remaining females occupied a $95 \%$ kernel contour of $284.2 \pm 523.7 \mathrm{~km}^{2}$ with a core area of $55.7 \pm 100.1 \mathrm{~km}^{2}$ - Table 2 and Fig. $2 \mathrm{c}$.

\subsection{Migration movements}

The post-nesting movements of the 11 females were recorded for 5 to $93 \mathrm{~d}$ (\#150117 vs. \#162269) - see Table 3. Three migratory patterns were observed, with four individuals migrating westward to the 


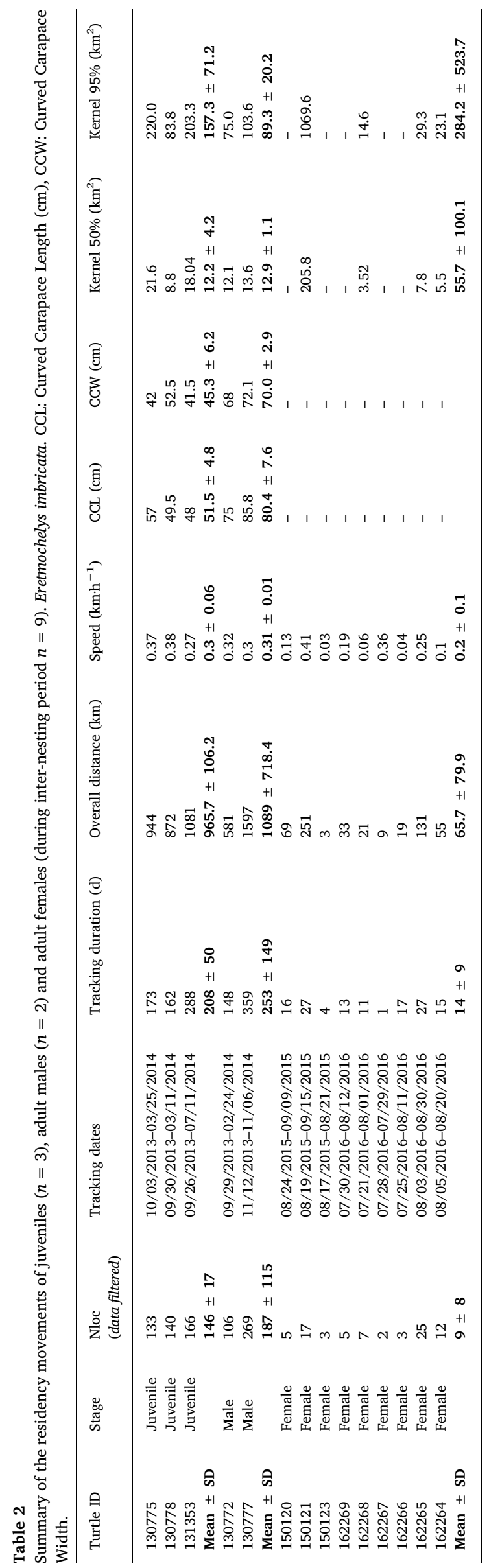

Nicaraguan coast, four others migrating southward to Grenada and Grenadines islands, and two females migrating northwards, reaching the Bahamas and the Turks and Caicos Islands (Fig. 1). The tag of the remaining female (\#150121) stopped emitting before she reached any foraging ground. Adult females traveled through the international waters of 31 exclusive economic zones (EEZ). During their migration, the females traveled $1707 \pm 1221 \mathrm{~km}$, for a straight-line distance of $1162 \pm 946 \mathrm{~km}$ and at an average speed of $1.88 \pm 0.4 \mathrm{~km} \cdot \mathrm{h}^{-1}$. Four stopovers were highlighted along these migratory pathways (Fig. 1), with a maximum of two stopovers obtained for a single turtle (\#162266). No stopover was identified for the turtles migrating southwards.

\subsection{Final foraging grounds}

Based on the analysis of the time spent per grid cell, eight potentials foraging grounds were identified across the Caribbean Sea. The tags of individuals \#150121, \#162265 and \#162267 ceased emitting after recording a few locations, thus excluding any identification of foraging areas. Three potential foraging grounds were identified off Nicaragua, where turtle \#150117 reached the biological reserve of Cayos Misquitos $\left(14^{\circ} 32 \mathrm{~N}, 82^{\circ} 41 \mathrm{~W}\right)$ and remained for $70 \mathrm{~d}$. Turtles \#150123 and \#162266 remained within the Bawihka Channel $\left(15^{\circ} 47 \mathrm{~N}\right.$, $81^{\circ} 41 \mathrm{~W}$ ) for $762 \mathrm{~d}$ and $108 \mathrm{~d}$, respectively.

Four other potential foraging areas were located further south of Martinique. The first, located north of Grenada Island $\left(12^{\circ} 13 \mathrm{~N}\right.$, $61^{\circ} 35 \mathrm{~W}$ ) was occupied by individual \#150120 during $63 \mathrm{~d}$. Individual \#150118 remained at the second foraging ground, located near Carriacou Island, for $118 \mathrm{~d}\left(12^{\circ} 29 \mathrm{~N}, 61^{\circ} 23 \mathrm{~W}\right)$.

Among the turtles equipped in 2016, individuals \#162264 and \#162268 remained close to St Vincent and the Grenadines Islands for 145 and $125 \mathrm{~d}$, respectively. Another female (\#162269) equipped in 2016 remained at a foraging ground located near Bahamas Island $\left(24^{\circ} 04 \mathrm{~N},-77^{\circ} 19 \mathrm{~W}\right)$ for $68 \mathrm{~d}$.

All of these females occupied a foraging area (95\% kernel contour) of $336 \pm 284.7 \mathrm{~km}^{2}$ in average (range: $43.5-802.4 \mathrm{~km}^{2}$, \#162269 vs. \#150118), with a core-use area (50\% kernel contour) of $52.4 \pm 49.5 \mathrm{~km}^{2}$ (range: $7.2-136.2 \mathrm{~km}^{2}, \# 162269$ vs. \#150118) - see Table 4.

\subsection{Diving behavior}

Despite inter-individual variability for maximum depth $(p<0.001$, $\left.\mathrm{X}^{2}=243\right)$ and dive duration $(p<0.001$, Kruskal-Wallis test, $\left.\mathrm{X}^{2}=124\right)$, the three juveniles performed mainly shallow $(15.6 \pm 9.6 \mathrm{~m})$ and long dives $(49 \pm 17 \mathrm{~min})-$ see Fig. $3 \mathrm{a}$ and b. At this depth range, seawater temperature records ranged from 27 to $33^{\circ} \mathrm{C}$ (mean: $28.9 \pm 1.3^{\circ} \mathrm{C}$ ) - see Fig. $3 \mathrm{c}$.

The males $(n=2)$ performed shallow $(96 \%$ at $0-20 \mathrm{~m}$, mean: $15.6 \pm 5.7 \mathrm{~m}$ ) and long dives (54\% between 60 and $70 \mathrm{~min}$, mean: $53.0 \pm 20.3 \mathrm{~min}$ ) - see Fig. $3 \mathrm{~d}$ and e. The mean temperature experienced by the males was an average $29.0 \pm 1.2^{\circ} \mathrm{C}$ (range: $27-32{ }^{\circ} \mathrm{C}$ ) see Fig. 3f. Similar to the observations in juveniles, the behavior of the two males differed in terms of depth $(p<0.001$, Mann Withney test, $\mathrm{W}=90,544)$ and duration $(p<0.001$, Mann Withney test, $\mathrm{W}=46,869$ ).

During the inter-nesting season, turtle \#150123 dived at a mean depth of $31.1 \pm 19.4 \mathrm{~m}$ ( $50 \%$ of dives were between 0 and $20 \mathrm{~m}$ ) during $19.6 \pm 18.6 \mathrm{~min}$ ( $57 \%$ lasted $0-10 \mathrm{~min})$ - see $\mathrm{Fig} .3 \mathrm{~g}$ and $\mathrm{h}$. During migration, this female spent $48 \%$ of the dives between 0 and $20 \mathrm{~m}$ and $37 \%$ between 40 and $60 \mathrm{~m}$ (mean: $30.2 \pm 22.2 \mathrm{~m}$ ) - see Fig. 3g. The average duration of these dives was $24.0 \pm 18.7 \mathrm{~min}(31 \%$ lasted $0-5 \mathrm{~min}$ and $24 \%$ lasted $35-40 \mathrm{~min}$ ) - see Fig. $3 \mathrm{~g}$ and h. At the foraging ground, this turtle dived to depths between 20 and $60 \mathrm{~m}$ (mean: $41.7 \pm 9.4 \mathrm{~m}$ ) over long periods ( $94 \%$ between 35 and $50 \mathrm{~min}$, mean: $42.9 \pm 8.9 \mathrm{~min}$ ) - see Fig. $3 g$ and $\mathrm{h}$. Dive depth and dive 

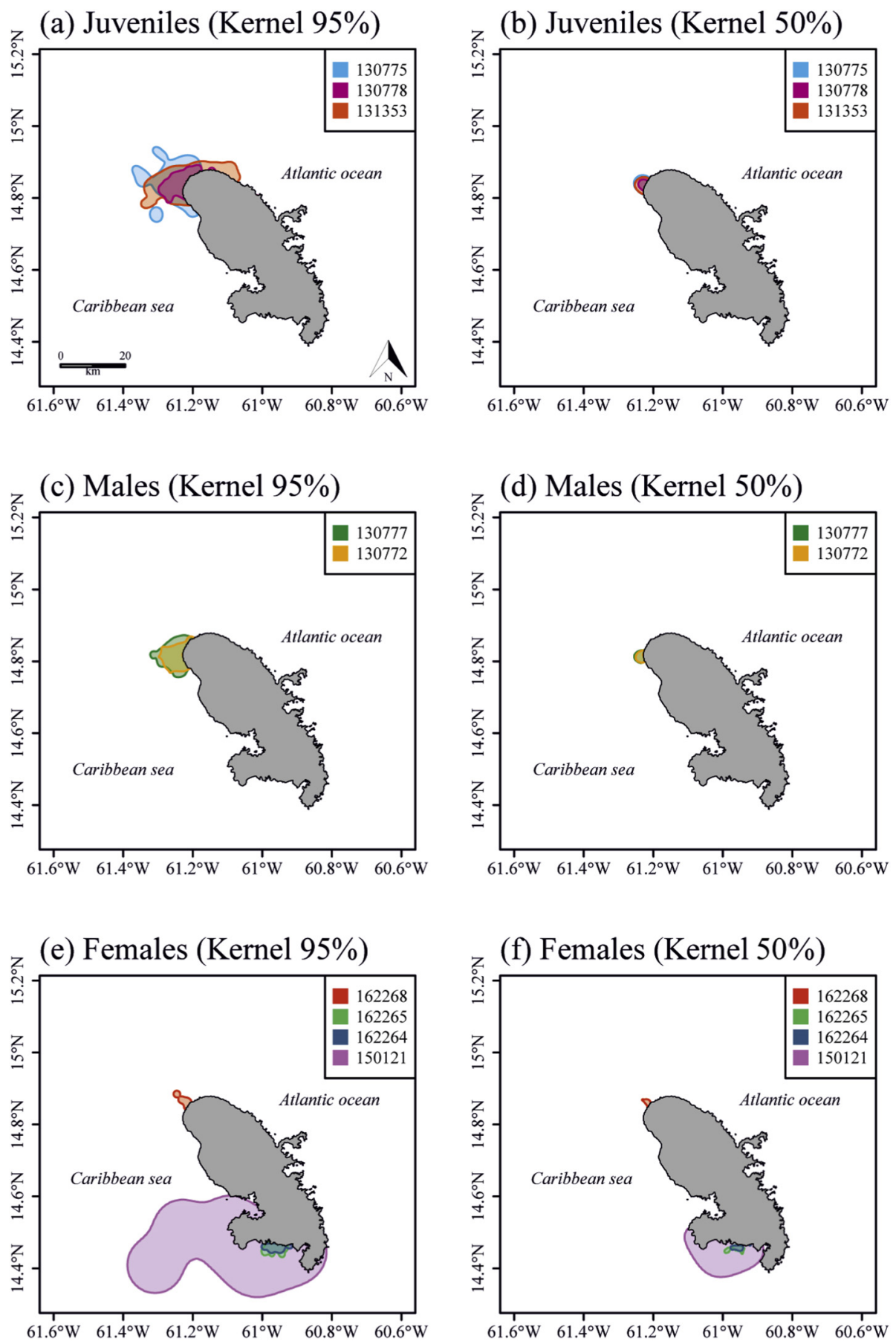

Fig 2. Kernel density contours (95\%: a, c, e and 50\%: b, d, f) for the juveniles (a and b, $n=3$ ), the adults males (b and c, $n=2$ ) and the females during the internesting season (c and d, $n=4$ ).

duration differed significantly between the three phases $(p<0.001$, Kruskal-Wallis test, $\mathrm{X}^{2}=26 ; p<0.001 v$ s. $\mathrm{X}^{2}=47$, respectively).

The temperatures experienced by the eleven adult females during the inter-nesting season varied from 28 to $33^{\circ} \mathrm{C}$ (mean: $29.2 \pm 0.7^{\circ} \mathrm{C}$ ) - Fig. 3i. During migration, the mean water temperature was $29.6 \pm 1.4^{\circ} \mathrm{C}$ (range: $26-33^{\circ} \mathrm{C}$ ) whereas it was an average $28.7 \pm 1.0$ (range: $24-33^{\circ} \mathrm{C}$ ) at the foraging ground. The mean water temperature therefore differed significantly between these three phases $(p<0.001$, Kruskal-Wallis test, $X^{2}=5440$ ).

While dive duration differed significantly different between adults and juveniles $\left(p<0.001\right.$, Kruskal-Wallis test, $\left.\mathrm{X}^{2}=344 ; p<0.001\right)$, dive depth did not (Wilcoxon test, $\mathrm{W}=7 ; p=0.4$ ). Among the adults, dive duration and dive depth differed significantly between individuals $\left(p<0.001\right.$, Kruskal-Wallis test, $\mathrm{X}^{2}=105 ; p<0.001, \mathrm{~W}=76$, respectively).

\section{Discussion}

This study provides the first description of horizontal and vertical movements of both juveniles and adults hawksbill turtles originating from the French West Indies. From an overlap between juveniles and males foraging home range to migrations corridors followed by postnesting females, this paper illustrates the diversity of behaviors undertaking by hawksbill turtles. 
Table 3

Summary of migratory movements of the adult females by migration orientation $(n=11)$.

\begin{tabular}{|c|c|c|c|c|c|c|c|}
\hline Turtle ID & End location & $\begin{array}{l}\text { Nloc } \\
\text { (data filtered) }\end{array}$ & Tracking dates & Tracking duration (d) & Distance $(\mathrm{km})$ & Speed $\left(\mathrm{km} \cdot \mathrm{h}^{-1}\right)$ & Straight line distance $\left(\mathrm{km}^{2}\right)$ \\
\hline 150117 & Nicaragua & 6 & 08/27/2015-10/26/2015 & 60 & 2508 & 2.18 & 2468 \\
\hline 150123 & Nicaragua & 152 & 08/23/2015-10/16/2015 & 54 & 2217 & 2.71 & 2214 \\
\hline 162266 & Nicaragua & 58 & 08/13/2016-10/06/2016 & 54 & 2677 & 2.04 & 2234 \\
\hline Mean \pm SD & & $72 \pm 74$ & & $56 \pm 3$ & $2467 \pm 232$ & $2.31 \pm 0.35$ & $2028 \pm 572$ \\
\hline 150118 & Grenada & 23 & 08/23/2015-08/28/2015 & 5 & 189 & 1.72 & 121 \\
\hline 150120 & Grenada & 12 & $11 / 09 / 2015-09 / 20 / 2015$ & 9 & 272 & 1.58 & 184 \\
\hline 162268 & St Vincent and Grenadines & 24 & 08/14/2016-08/27/2016 & 13 & 373 & 1.64 & 231 \\
\hline 162264 & St Vincent and Grenadines & 59 & $08 / 20 / 2016-08 / 30 / 2016$ & 10 & 404 & 1.91 & 227 \\
\hline Mean \pm SD & & $29 \pm 20$ & & $9 \pm 3$ & $309 \pm 98$ & $1.71 \pm 0.1$ & $191 \pm 51$ \\
\hline 162267 & Bahamas & 358 & $07 / 29 / 2016-08 / 30 / 2016$ & 32 & 1795 & 2.8 & 1371 \\
\hline 162269 & Turks and Caicos & 605 & 08/12/2016-11/13/2016 & 93 & 2857 & 1.8 & 1890 \\
\hline Mean \pm SD & & $481 \pm 175$ & & $62 \pm 43$ & $2326 \pm 751$ & $2.30 \pm 0.7$ & $1630 \pm 367$ \\
\hline 150121 & Caribbean sea & 27 & 09/15/2015-10/23/2015 & 38 & 1627 & 2.1 & 1381 \\
\hline 162265 & Caribbean sea & 385 & 08/30/2016-11/13/2016 & 75 & 2491 & 1.74 & 433 \\
\hline Mean \pm SD & & $192 \pm 236$ & & $73 \pm 118$ & $1707 \pm 1221$ & $1.88 \pm 0.4$ & $1162 \pm 946$ \\
\hline
\end{tabular}

\subsection{Residential key areas}

The three tracked juveniles established their foraging home ranges in a relatively small area north of Martinique (mean: $157 \pm 71 \mathrm{~km}^{2}$ ). Previous study estimating home ranges of juvenile hawksbills in the Caribbean Sea in Puerto Rico reported areas of less than $\leq 1 \mathrm{~km}^{2}$ (Van Dam and Diez, 1998). This substantial difference is likely due to the longer tracking duration in our study ( $188 \mathrm{~d} v s .11-16 \mathrm{~d}$ ), but also to the tracking method used (telemetry $v s$. sonic tags). Even if the results of home range size reported here are likely to be overestimation of real home range as implemented tags have recorded only Argos position (Hoenner et al., 2012), these results supports the residential behavior of this species over a longer period. Supplementary caution should be taken when considering home range size, as it is largely determined by the choice of bandwidth for the kernel calculation (Kie, 2013). Although our home range estimation would be more accurate with GPS positions, our study highlighted a shared foraging habitat for juveniles and adult males, which is consistent with another study conducted in Puerto Rico (Diez and Van Dam, 2002). This finding suggests that this area could offer sufficient resources to be shared by two different life stages and therefore underlines the necessity to protect such habitats. Nonetheless, additive studies are required to determine level of protection and priorities at regional scale. Compared to juveniles and males, females established a larger home range in their foraging grounds (mean: $336 \pm 284.7 \mathrm{~km}^{2}$ ). The foraging home range size may be related to the spatial distribution of food within the area (Makowski et al., 2006) but the lack of knowledge on seascapes in these areas limits our capacity to make inferences.

Four of the satellite-tracked females established their inter-nesting home range close to the site where they were tagged during the internesting phase, confirming strong site fidelity (Starbird et al., 1999; Troëng et al., 2005a; Whiting et al., 2006; Walcott et al., 2012). Females displayed a short distance displacement with a restricted home- range area which may indicate a resting behavior, likely due to the high energy demands of the inter-nesting period (Zbinden et al., 2007; Santos et al., 2010). One of the tracked females (\#150121) adopted a surprising behavior by undertaking a return trip of $220 \mathrm{~km}$ from SainteLucia Island immediately after being tagged (see Fig. 1) and established a larger inter-nesting home range in Martinique than other individuals (Fig. 2f). This movement pattern could mean that the female gathering information for decisions about mating, resource use or long-distance movements (Schofield et al., 2010; Kays et al., 2015). A larger number of locations would provide a better estimation of home range size. In future studies, additional gravid females should be equipped earlier in the nesting season to increase the sample size and therefore confirm the home ranges estimated in this study.

\subsection{Behavioral plasticity in post-nesting migratory routes and foraging hotspots}

While Martinique Island is known to host numerous hawksbills female turtles every year, their migratory movements had not been documented before this study. Our results highlight a dichotomy in the migratory movements of these females and are therefore in accordance with previous studies conducted in the Caribbean Sea (Horrocks et al., 2001; Moncada et al., 2012). Five females performed a long migration, heading either westwards towards the Nicaraguan coast (mean: $2467 \pm 232 \mathrm{~km}$ ) or northwards towards the Bahamas (mean: $2326 \pm 751 \mathrm{~km})$, whereas the four remaining females performed shorter migrations (mean: $309 \pm 98 \mathrm{~km}$ ) to locations closer to the nesting beach, such as Sainte-Lucia and the Grenadine Islands. These multidirectional migrations are consistent with population genetic studies showing that nesting populations originate from strong genetic mixing (Bass, 1999; Browne et al., 2010). One of the individuals (\#162265) appears to have taken a circular oceanic movement (Fig. 1), which are inconsistent with other individuals travelling in straight line.

Table 4

Summary of the horizontal movements of adult females at foraging grounds $(n=9)$.

\begin{tabular}{|c|c|c|c|c|c|}
\hline Turtle ID & $\begin{array}{l}\text { Nloc } \\
\text { (data filtered) }\end{array}$ & Tracking dates & Tracking duration (d) & Kernel $50 \%\left(\mathrm{~km}^{2}\right)$ & Kernel 95\% $\left(\mathrm{km}^{2}\right)$ \\
\hline 150117 & 28 & $10 / 26 / 2015-01 / 04 / 2016$ & 70 & 123.2 & 731.6 \\
\hline 150118 & 43 & $08 / 28 / 2015-12 / 24 / 2015$ & 118 & 136.2 & 802.4 \\
\hline 150120 & 20 & 09/23/2015-11/25/2015 & 63 & 43.9 & 187.6 \\
\hline 150123 & 584 & $10 / 16 / 2015-11 / 16 / 2017$ & 762 & 29.3 & 343.0 \\
\hline 162269 & 55 & $11 / 13 / 2016-01 / 20 / 2017$ & 68 & 7.2 & 43.5 \\
\hline 162268 & 85 & 09/03/2016-01/06/2017 & 125 & 42.4 & 314.6 \\
\hline 162266 & 97 & $10 / 07 / 2016-01 / 23 / 2017$ & 108 & 23.7 & 162.3 \\
\hline 162264 & 140 & 08/31/2016-01/23/2017 & 145 & 13.3 & 101.7 \\
\hline Mean \pm SD & $131 \pm 187$ & & $182 \pm 236$ & $52.4 \pm 49.5$ & $336 \pm 284.7$ \\
\hline
\end{tabular}


(a) Juveniles

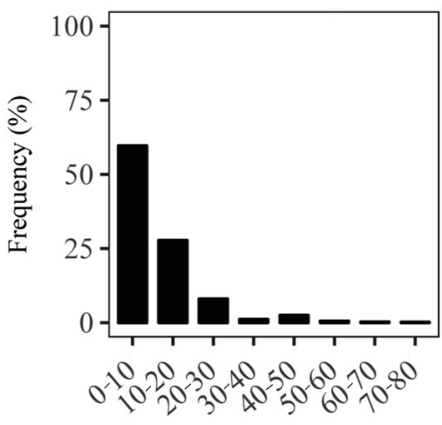

(d) Males

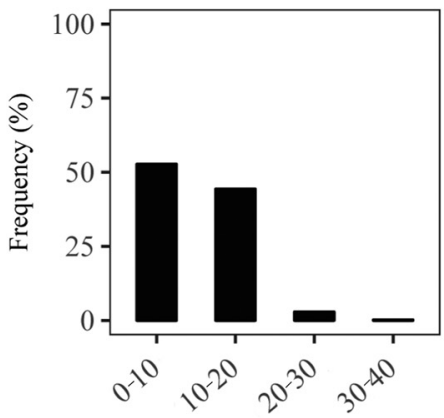

(g) Female

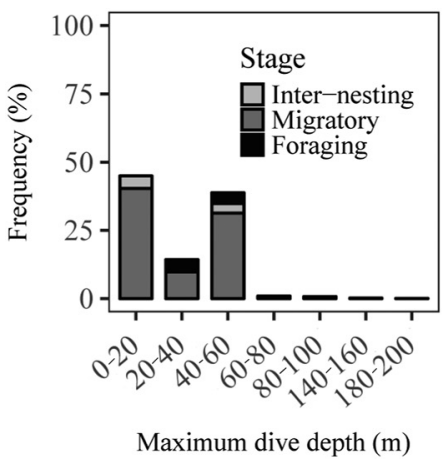

(b) Juveniles

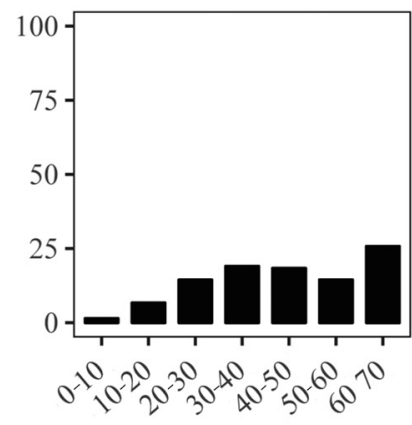

(e) Males

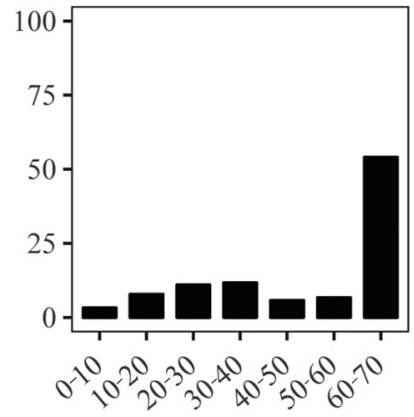

(h) Female

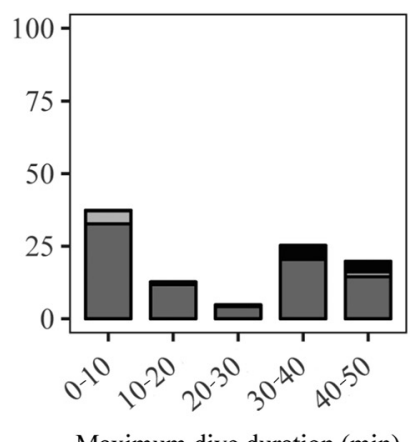

(c) Juveniles

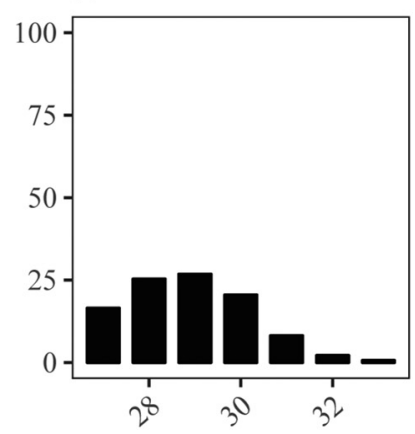

(f) Males

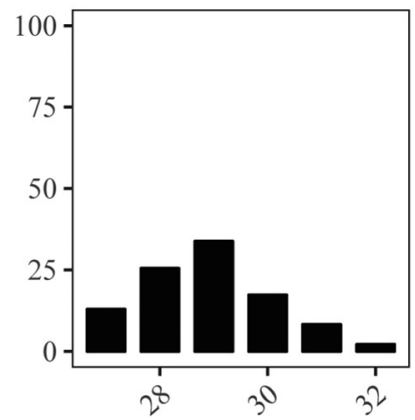

(i) Female

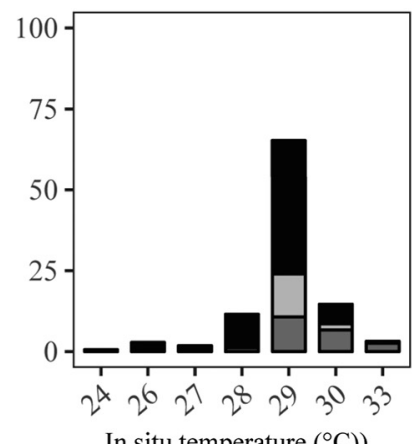

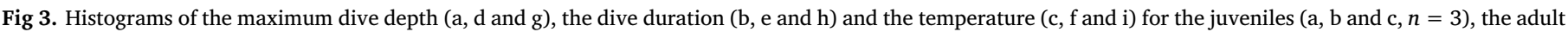
males (d, e and f, $n=2$ ) and the female ( $g$, h and I, $n=1)$.

This looping behavior patterns has been observed on green turtles, following surface currents before reaching benthic foraging grounds (Cheng, 2000). This may reflect prospecting searches for potential feeding sites (Troëng et al., 2005b) or disorientation (Luschi et al., 2001) and difficulties to collect navigational information.

Among the eight potential foraging areas identified in our study, three tend to confirm that the Nicaraguan coast is an important foraging area for this species (Cuevas et al., 2008; Hawkes et al., 2012; Moncada et al., 2012), likely due to the presence of large coral reefs (Augier, 2010) which are also part of their diet (Meylan, 1988; Anderes and Uchida, 1994; Rincon-Diaz et al., 2011). Most of the tracked individuals seemed to correct their courses, especially during the final stage of their migration, as they are reaching their final destination after long detours. Sea current flows and eddies could have interfered with sea turtles journey as it can deflect them from the optimal routes (Luschi et al., 2003). Thus, observing detours could be a result of the "Zermelo navigation problem" as suggested by Hays et al. (2014). Sea turtles would often fail to solve the 'Zermelo navigation problem', defined as finding the optimum routes despite cross flow (Zermelo, 1931), and therefore do not systematically follow the optimum route to foraging grounds.

Migration demands high amounts of energy and the need for a stopover site along the migratory routes is well known for many species such as mammals (Sawyer and Kauffman, 2011) and birds (Lupi et al., 2016; Bayly et al., 2017). So far, only three studies have detected the use of stopovers by sea turtles, on green turtle Chelonia mydas (Baudouin et al., 2015; Rice and Balazs, 2008) and hawksbill turtles (Cuevas et al., 2008). Our study reports the use of stopover sites during the migration of hawksbill turtles in the Caribbean. This behavior was mainly observed in neritic habitats, with the exception of one stopover located in oceanic habitats for individuals undertaking long oceanic migration. Turtles may use stopover sites to compensate for energy loss during such long migration, likely to rest and/or possibly feed to restore their body reserves before reaching their final feeding areas (Baudouin 
et al., 2015).

\subsection{Diving behavior}

As previously suggested in several studies conducted on hawksbill turtles, we expected the tracked individuals to concentrate their activities within depths of up to $20 \mathrm{~m}$ (Blumenthal et al., 2009a; Van Dam \& Diez, 1996 \& 1997). Our results showed similar diving patterns for both juveniles and males tracked in Martinique, both of which performed mainly shallow and long dives. They occasionally dived deeper than $20 \mathrm{~m}$, with some juveniles performing dives of up to $80 \mathrm{~m}$. Diving behavior could be influenced by the spatial distribution of preferred dietary items (Hays et al., 2006), physical conditions (wave action), or predator avoidance tactics (Van Dam and Diez, 1996; Heithaus et al., 2007). Inferences on foraging ecology of hawksbill turtles are limited by the lack of studies on hawksbill diet in the region. However, sponges usually dominate both in terms of biomass and diversity at shallow depths (0-30 m; Pérez et al., 2017), possibly due to the greater availability of light (Pawlik et al., 2013). Despite the actual lack of literature on the distribution of sponges in Martinique waters, the depths reached by both the juveniles and the males tracked in Martinique may match the presence of this resource. This hypothesis needs to be confirmed by additional research, including the determination of the vertical distribution of prey resources in the water columns in the identified hawksbill home ranges.

Similarly, the female tracked during the inter-nesting period performed mainly shallow dives within the first $20 \mathrm{~m}$ of water depth. Given that the bathymetry around the Martinique falls rapidly to several hundred meters (AAMP and DIREN Martinique, 2010), this result shows the fidelity of turtles to sites close to the shore. Hawksbill turtles remaining close to the shore have already been highlighted by previous studies (Mortimer and Portier, 1989, Marcovaldi et al., 2012, Gaos et al., 2012b). However, this female also performed a significant number of her dives between 50 and $60 \mathrm{~m}$. As sea turtles have the capacity to adjust their buoyancy by controlling their lung volume, their dive depth is therefore generally constrained within the range over which the buoyancy can be regulated (Hays et al., 2000 \& 2004). The observed depth variation could suggest an opportunistically foraging behavior (Walcott et al., 2013; Van Dam and Diez, 1996). Such hypothesis is reinforced by a recent study revealing high sponge biomass and species diversity, particularly along the Caribbean side of Martinique Island (Pérez et al., 2017). The interpretation of our results is however limited by the sample size $(n=1)$ and the short tracking duration on the inter-nesting habitat. The use of devices that generate high resolution dive profiles or other techniques such as the InterMandibular Angle Sensor (IMASEN) recording the mouth opening and buccal pumping should be implemented to explore these hypothesis by revealing the potential foraging behavior (Houghton et al., 2008; Walcott et al., 2013). The regular dive pattern observed on the foraging grounds was characterized by depth concentrated between 30 and $50 \mathrm{~m}$ and a large majority of long dives (40-50 $\mathrm{min}$ ) which is in accordance with the results of Storch (2003) who have observed a more uniform behavior during the foraging phase than during the inter-nesting season.

During migration, we observed a biphasic diving behavior, characterized by shallow dives $(0-20 \mathrm{~m})$ and deepest dives $(40-60 \mathrm{~m})$, even up to $200 \mathrm{~m}$. This type of behavior has already been reported for green turtles undertaking oceanic migration (Rice and Balazs, 2008; Hays et al., 2001). As suggested by Hays et al. (2001), swimming at great depth could be linked to an avoidance tactic of visual predator like large pelagic sharks by reducing the risk of being spotted thanks to their dorso-ventral countershading. Although it has been showed in laboratory that green turtles can survive at dives deeper than $200 \mathrm{~m}$ (Berkson, 1967), the occurrence of such deep dives has never been reported for the hawksbill species to date and such hypothesis needs further investigation to attest that it is not due to an Argos error.

\subsection{Conclusion and conservation's implications}

Historical inventories carried out during the last hundred years, enabled to estimate the decline of hawksbill's populations worldwide to 90\% (Mortimer and Donnelly, 2008). This study highlighted for the first-time critical hotspots identified both in Martinique waters and across the Caribbean Sea for both sexes and different life stages. The characterized behavior in shallow waters and close to the shore in these areas highlights a possible overlap between important turtle habitats and anthropogenic potential impacts. As the importance of daily adult movements has been recognized for marine protected area design, results of this study can help to take site-specific measures. Moreover, knowledges on location and extent of predictable temporary habitat use as inter-nesting areas are important to define which areas are good candidates for temporary protection and prioritize seasonally abundant migratory species (D'Aloia et al., 2017). Information provided on the post-nesting migratory behavior of hawksbill turtles nesting on this island revealed regional connectivity between Caribbean Islands and reinforces the significance of a cooperative network at the Caribbean scale to ensure the efficient conservation of this critically endangered species. Among the five foraging grounds identified,

\section{Acknowledgements}

This study was carried out within the framework of the Plan National d'Action Tortues Marines de Martinique (PNATMM). This study was co-financed by the FEDER Martinique (European Union, Conventions 2012/DEAL/0010/4-4/31882 \& 2014/DEAL/0008/4-4/ 32947), DEAL Martinique (Conventions 2012/DEAL/0010/4-4/31882 \& 2014/DEAL/0008/4-4/32947), the ODE Martinique (Convention 014-03-2015), the CNRS (Subvention Mission pour l'Interdisciplinarité), the ERDF fund (Convention CNRS-EDFjuillet2013) and the Fondation de France (Subvention Fondation Ars Cuttoli Paul Appell). The authors also appreciate the support of the ANTIDOT project (Pépinière Interdisciplinaire Guyane, Mission pour l'Interdisciplinarité, CNRS). The authors would like to thank the DEAL Martinique, the ODE Martinique, the ONCFS Martinique, the ONEMA Martinique, the SMPE Martinique, the ONF Martinique, the PNR Martinique, the Surfrider Foundation, Aquasearch, CREOCEAN, Carbet des Sciences, Aliotis plongée, Plongée-Passion, the Collège Cassien Sainte-Claire and the Collège Petit Manoir for their technical support and field assistance. We are also grateful to the numerous volunteers and freedivers for their participation in the field operations.

\section{References}

AAMP \& DIREN Martinique, 2010. Analyse Stratégique Régionale Martinique Synthèse des connaissances. In: Agence des Aires Marines Protégées, pp. 156.

Allen, A.M., Singh, N.J., 2016. Linking movement ecology with wildlife management and conservation. Front. Ecol. Evol. 3 (155). http://dx.doi.org/10.3389/fevo.2015. 00155.

Anderes, B.L., Uchida, I., 1994. Study of the hawksbill turtle (Eretmochelys imbricata) stomach content in Cuban waters. In: Study of the Hawksbill Turtle in Cuba.

Augier, D., 2010. Les écosystèmes marins de la Caraïbe: identification, diffusion et modes de gestion. Etudes Caribéennes, [En ligne], 15 | Avril 2010, mis en ligne le 10 janvier 2011, consulté le 23 mai 2016. URL. http://etudescaribeennes.revues.org/4343.

Bass, A.L., 1999. Genetic analysis to elucidate the natural history and behavior of hawksbill turtles (Eretmochelys imbricata) in the wider Caribbean: a review and reanalysis. Chelonian Conserv. Biol. 3 (2), 195-199.

Baudouin, M., de Thoisy, B., Chambault, P., Berzins, R., Entraygues, M., Kelle, L., Turny, A., Le Maho, Y., Chevallier, D., 2015. Identification of key marine areas for conservation based on satellite tracking of post-nesting migrating green turtles (Chelonia mydas). Biol. Conserv. 184, 36-41. http://dx.doi.org/10.1016/j.biocon.2014.12.021.

Bayly, N.J., Gómez, C., Hobson, K.A., González, A.M., Rosenberg, K.V., 2017. Fall migration of the veery (catharus fuscescens) in northern Colombia: determining the energetic importance of a stopover site. Auk 129 (3), 449-459.

Berkson, H., 1967. Physiological adjustments to deep diving in the Pacific green turtle (Chelonia mydas agassizii). Comp. Biochem. Physiol. 21 (3), 507-524.

Bivand, R., Rundel, C., 2017. rgeos: Interface to Geometry Engine - Open Source (GEOS). R Package Version 0.3-23.

Blanco, G.S., Morreale, S.J., Seminoff, J.A., Paladino, F.V., Piedra, R., Spotila, J.R., 2013. 
Movements and diving behavior of internesting green turtles along Pacific Costa Rica. Integr. Zool. 8 (3), 293-306. http://dx.doi.org/10.1111/j.1749-4877.2012.00298.x.

Blumenthal, J.M., Austin, T.J., Bothwell, J.B., Broderick, A.C., Ebanks-Petrie, G., Olynik, J.R., Orr, M.F., Solomon, J.L., Witt, M.J., Godley, B.J., 2009a. Diving behavior and movements of juvenile hawksbill turtles Eretmochelys imbricata on a Caribbean coral reef. Coral Reefs 28 (1), 55-65. http://dx.doi.org/10.1007/s00338-008-0416-1.

Blumenthal, J.M., Austin, T.J., Bell, C.D.L., Bothwell, J.B., Broderick, A.C., Ebanks-Petrie, G., ... Solomon, J.L., 2009b. Ecology of hawksbill turtles, Eretmochelys imbricata, on a western Caribbean foraging ground. Chelonian Conserv. Biol. 8 (1), 1-10.

Browne, D.C., Horrocks, J.A., Abreu-Grobois, F.A., 2010. Population subdivision in hawksbill turtles nesting on Barbados, West Indies, determined from mitochondrial DNA control region sequences. Conserv. Genet. 11 (4), 1541-1546. http://dx.doi. org/10.1007/s10592-009-9883-3.

Cagnacci, F., Boitani, L., Powell, R.A., Boyce, M.S., 2010. Animal ecology meets GPSbased radiotelemetry: a perfect storm of opportunities and challenges. Philos. Trans. R. Soc. B 365, 2157-2162.

Calenge, C., 2006. The package adehabitat for the R software: a tool for the analysis of space and habitat use by animals. Ecol. Model. 197, 516-519.

Chambault, P., Pinaud, D., Vantrepotte, V., Kelle, L., Entraygues, M., Guinet, C., Berzins, R., Bilo, K., Gaspar, P., de Thoisy, B., Le Maho, Y., Chevallier, D., 2015. Dispersal and diving adjustments of the green turtle Chelonia mydas in response to dynamic environmental conditions during post-nesting migration. PLoS One 10 (9), e0137340. http://dx.doi.org/10.1371/journal.pone.0137340.

Chambault, P., de Thoisy, B., Heerah, K., Conchon, A., Barrioz, S., Dos Reis, V., Berzins, R., Kelle, L., Picard, B., Roquet, F., Le Maho, Y., Chevallier, D., 2016a. The influence of oceanographic features on the foraging behavior of the olive ridley sea turtle Lepidochelys olivacea along the Guiana coast. Prog. Oceanogr. 142, 58-71. http://dx. doi.org/10.1016/j.pocean.2016.01.006.

Chambault, P., de Thoisy, B., Kelle, L., Berzins, R., Bonola, M., Delvaux, H., Le Maho, Y., Chevallier, D., 2016b. Inter-nesting behavioural adjustments of green turtles to an estuarine habitat in French Guiana. Mar. Ecol. Prog. Ser. 555, 235-248. http://dx. doi.org/10.3354/meps11813.

Cheng, I.J., 2000. Post-nesting migrations of green turtles (Chelonia mydas) at Wan-An Island, Penghu Archipelago, Taiwan. Mar. Biol. 137, 747-754.

Chevalier, J., 2006. Plan de restauration des tortues marines des Antilles françaises. 162 Office National de la Chasse et de la Faune Sauvage, Fort-de-France.

Costa, D.P., Robinson, P.W., Arnould, J.P.Y., Harrison, A.L., Simmons, S.E., Hassrick, J.L., Hoskins, A.J., Kirkman, S.P., Oosthuizen, H., Villegas-Amtmann, S., Crocker, D.E., 2010. Accuracy of ARGOS locations of pinnipeds at-sea estimated using fastloc GPS. PLoS One 5 (1). http://dx.doi.org/10.1371/journal.pone.0008677.

Cuevas, E., Abreu-Grobois, F., Guzmán-Hernández, V., Liceaga-Correa, M., van Dam, R., 2008. Post-nesting migratory movements of hawksbill turtles Eretmochelys imbricata in waters adjacent to the Yucatan Peninsula, Mexico. Endanger. Species Res. 10, 123-133. http://dx.doi.org/10.3354/esr00128.

D'Aloia, C.C., Daigle, R.M., Côté, I.M., Curtis, J.M., Guichard, F., Fortin, M.J., 2017. A multiple-species framework for integrating movement processes across life stages into the design of marine protected areas. Biol. Conserv. 216, 93-100.

Diez, C.E., Van Dam, R.P., 2002. Habitat effect on hawksbill turtle growth rates on feeding grounds at Mona and Monito Islands, Puerto Rico. Mar. Ecol. Prog. Ser. 234, 301-309. http://dx.doi.org/10.3354/meps234301.

Ferreira, R.L., Ceia, F.R., Borges, T.C., Ramos, J.A., Bolten, A.B., 2018. Foraging niche segregation between juvenile and adult hawksbill turtles (Eretmochelys imbricata) at Príncipe island, West Africa. J. Exp. Mar. Biol. Ecol. 498, 1-7.

Gaos, A.R., Lewison, R.R., Wallace, B.P., Yañez, I.L., Liles, M.J., Baquero, A., Seminoff, J.A., 2012a. Dive behaviour of adult hawksbills (Eretmochelys imbricata, Linnaeus 1766) in the eastern Pacific Ocean highlights shallow depth use by the species. J. Exp. Mar. Biol. Ecol. 432-433, 171-178. http://dx.doi.org/10.1016/j.jembe.2012.07.006.

Gaos, A.R., Lewison, R., Wallace, B., Yanez, I., Liles, M.J., Nichols, W.J., Baquero, A. Hasbùn, C.R., Vasquez, M., Urteaga, J., Seminoff, J.A., 2012b. Spatial ecology of critically endangered hawksbill turtles Eretmochelys imbricata: implications for management and conservation. Mar. Ecol. Prog. Ser. 450, 181-194. http://dx.doi.org/10. 3354/meps09591.

Hamann, M., Godfrey, M.H., Seminoff, J.A., Arthur, K., Barata, P.C.R., Bjorndal, K.A., ... Godley, B.J., 2010. Global research priorities for sea turtles: informing management and conservation in the 21st century. Endanger. Species Res. 11 (3), 245-269. http:// dx.doi.org/10.3354/esr00279.

Hart, K.M., Sartain, A.R., Fujisaki, I., Pratt, H.L., Morley, D., Feeley, M.W., 2012. Home range, habitat use, and migrations of hawksbill turtles tracked in the Dry Tortugas National Park, Florida, USA. Mar. Ecol. Prog. Ser. 457, 193-207.

Hawkes, L.A., Tomàs, J., Revuelta, O., León, Y.M., Blumenthal, J.M., Broderick, A.C., ... Godley, B.J., 2012. Migratory patterns in hawksbill turtles described by satellite tracking. Mar. Ecol. Prog. Ser. 461, 223-232. http://dx.doi.org/10.3354/ meps09778.

Hays, G.C., Adams, C.R., Broderick, A.C., Godley, G.J., Lucas, D.J., Metcalfe, J.D., Prior, A.A., 2000. The diving behaviour of green turtles at Ascension Island. Anim. Behav. 59 (3), 577-586.

Hays, G.C., Akesson, S., Broderick, A.C., Glen, F., Godley, B.J., Luschi, P., Martin, C., Metcalfe, J.D., Papi, F., 2001. The diving behavior of green turtles undertaking oceanic migration to and from Ascension Island: dive durations, dive profiles and depth distribution. J. Exp. Biol. 204, 4093-4098.

Hays, G.C., Metcalfe, J.D., Walne, A.W., 2004. The implications of lung-regulated buoyancy control for dive depth and duration. Ecology 85 (4), 1137-1145. http://dx.doi. org/10.1890/03-0251.

Hays, G., Hobson, V., Metcalfe, J.D., Righton, D., Sims, D.W., 2006. Flexible foraging movements of leatherback turtles across the North Atlantic Ocean. Ecology 87 (10), 2647-2656. http://dx.doi.org/10.1890/0012-9658(2006)87[2647:FFMOLT]2.0.
$\mathrm{CO} ; 2$.

Hays, G.C., Christensen, A., Fossette, S., Schofield, G., Talbot, J., Mariani, P., 2014. Route optimisation and solving Zermelo's navigation problem during long distance migration in cross flows. Ecol. Lett. 17, 137-143.

Hays, G.C., Ferreira, L.C., Sequeira, A.M., Meekan, M.G., Duarte, C.M., Bailey, H., Eguíluz, V.M., 2016. Key questions in marine megafauna movement ecology. Trends Ecol. Evol. 31 (6), 463-475.

Heithaus, M.R., Frid, A., Wirsing, A.J., Dill, L.M., Fourqurean, J.W., Burk-holder, D., Thomson, J., Bejder, O.L., 2007. State-dependent risk-taking by green sea turtles mediates top-down eVects of tiger shark intimidation in a marine ecosystem. J. Anim. Ecol. 76, 837-844.

Hoenner, X., Whiting, S.D., Hindell, M.A., McMahon, C.R., 2012. Enhancing the use of argos satellite data for home range and long distance migration studies of marine animals. PLoS One 7 (7), e40713. http://dx.doi.org/10.1371/journal.pone.0040713.

Horrocks, J.A., Vermeer, L., Krueger, B., Coyne, M., Schroeder, B., Balazs, G.H., 2001. Migration routes and destination characteristics of post-nesting hawksbill turtles satellite-tracked from Barbados, West Indies. Chelonian Conserv. Biol. 4 (1), $107-114$.

Houghton, J.D.R., Cedras, A., Myers, A.E., Liebsch, N., Metcalfe, J.D., Mortimer, J.A., Hays, G.C., 2008. Measuring the state of consciousness in a free-living diving sea turtle. J. Exp. Mar. Biol. Ecol. 356 (1-2), 115-120. http://dx.doi.org/10.1016/j. jembe.2007.12.008.

Kays, R., Crofoot, M.C., Jetz, W., Wikelski, M., 2015. Terrestrial animal tracking as an eye on life and planet. Science 348,6240 . http://dx.doi.org/10.1126/science.aaa2478.

Kie, J.G., 2013. A rule-based ad hoc method for selecting a bandwidth in kernel homerange analyses. Anim. Biotelem. 1, 13.

León, Y.M., Bjorndal, K.A., 2002. Selective feeding in the hawksbill turtle, an important predator in coral reef ecosystems. Mar. Ecol. Prog. Ser. 245, 249-258.

Limpus, C.J., 1992. The hawksbill turtle, Eretmochelys imbricata, in Queensland: population structure within a southern great barrier reef feeding ground. Aust. Wildl. Res. 19, 489-506.

Lupi, S., Goymann, W., Cardinale, M., Fusani, L., 2016. Physiological conditions inluence stopover behavior of short-distance migratory passerines. J. Ornithol. 157, 583-589.

Luschi, P., Åkesson, S., Broderick, A.C., Glen, F., Godley, B.J., Papi, F., Hays, G.C., 2001. Testing the navigational abilities of ocean migrants: displacement experiments on green sea turtles (Chelonia mydas). Behav. Ecol. Sociobiol. 50 (6), 528-534.

Luschi, P., Hays, G., Papi, F., 2003. A review of long-distance movements by marine turtles, and the possible role of ocean currents. Oikos 103 (2), 293-302.

Makowski, C., Seminoff, J.A., Salmon, M., 2006. Home range and habitat use of juvenile Atlantic green turtles (Chelonia mydas L.) on shallow reef habitats in Palm Beach, Florida, USA. Mar. Biol. 148, 1167-1179. http://dx.doi.org/10.1007/s00227-0050150-y.

Marcovaldi, M.Â., Lopez, G.G., Soares, L.S., López-Mendilaharsu, M., 2012. Satellite tracking of hawksbill turtles Eretmochelys imbricata nesting in northern Bahia, Brazil: turtle movements and foraging destinations. Endanger. Species Res. 17 (2), 123-132.

Meylan, A.B., 1988. Spongivory in hawksbill turtles: a diet of glass. Science 239 (4838), 393-395.

Meylan, A.B., 1999. International movements of immature and adult hawksbill turtles (Eretmochelys imbricata) in the Caribbean region. Chelonian Conserv. Biol. 3 (2), 189-194.

Meylan, P.A., 2011. The ecology and migrations of sea turtles. Bull. Am. Mus. Nat. Hist. $357,1-70$.

Moncada, F.G., Hawkes, L.A., Fish, M.R., Godley, B.J., Manolis, S.C., Medina, Y., Nodarse, G., Webb, G.J.W., 2012. Patterns of dispersal of hawksbill turtles from the Cuban shelf inform scale of conservation and management. Biol. Conserv. 148 (1), 191-199. http://dx.doi.org/10.1016/j.biocon.2012.01.011.

Mortimer, J.A., Donnelly, M., 2008. Hawksbill turtle (Eretmochelys imbricata). In: Marine Turtle Specialist Group 2008 IUCN Red List Status Assessment. IUCN RedList, pp. 108.

Mortimer, J.A., Portier, K.M., 1989. Reproductive homing and internesting behavior of the green turtle (Chelonia mydas) at Ascension Island, South Atlantic Ocean. Copeia 1989, 962-977.

Okuyama, J., Kataoka, K., Kobayashi, M., Abe, O., Yoseda, K., Arai, N., 2012. The reg ularity of dive performance in sea turtles: a new perspective from precise activity data. Anim. Behav. 84 (2), 349-359. http://dx.doi.org/10.1016/j.anbehav.2012.04. 033.

Pawlik, J.R., Loh, T.L., McMurray, S.E., Finelli, C.M., 2013. Sponge communities on Caribbean coral reefs are structured by factors that are top-down, not bottom-up. PLoS One 8 (5). http://dx.doi.org/10.1371/journal.pone.0062573.

Pérez, T., Díaz, M.C., Ruiz, C., Cóndor-Luján, B., Klautau, M., Hajdu, E., ... Boury-Esnault, N., 2017. How a collaborative integrated taxonomic effort has trained new spongiologists and improved knowledge of Martinique Island (French Antilles, eastern Caribbean Sea) marine biodiversity. PLoS One 12 (3), 1-27. http://dx.doi.org/10. 1371/journal.pone.0173859.

Pilcher, N.J., Antonopoulou, M., Perry, L., Abdel-Moati, M.A., Al Abdessalaam, T.Z. Albeldawi, M. Al Ansi, M., Al-Mohannadi, S.F., Al Zahlawi, N., Baldwin, R., Chikhi, A., Das, H.S., Hamza, S., Kerr, O.J., Al Kiyumi, A., Mobaraki, A., Al Suwaidi, H.S., Al Suweidi, A.S., Sawaf, M., Tourenq, C., Williams, J., Willson, A., 2014. Identification of important sea turtle areas (ITAs) for hawksbill turtles in the Arabian region. J. Exp. Mar. Biol. Ecol. 460, 89-99.

R Core Team, 2017. R: A Language and Environment for Statistical Computing. R Foundation for Statistical Computing, Vienna, Austria URL. http://www.R-project. org/.

Rees, A.F., Alfaro-Shigueto, J., Barata, P.C.R., Bjorndal, K.A., Bolten, A.B., Bourjea, J., ... Godley, B.J., 2016. Are we working towards global research priorities for management and conservation of sea turtles? Endanger. Species Res. 31, 337-382. http://dx. 
doi.org/10.3354/esr00801.

Rice, M.R., Balazs, G.H., 2008. Diving behavior of the Hawaiian green turtle (Chelonia mydas) during oceanic migrations. J. Exp. Mar. Biol. Ecol. 356, 121-127. http://dx. doi.org/10.1016/j.jembe.2007.12.010.

Rincon-Diaz, M.P., Diez, C.E., Van Dam, R.P., Sabat, A.M., 2011. Foraging selectivity of the hawksbill sea turtle (Eretmochelys imbricata) in the Culebra archipelago, Puerto Rico. J. Herpetol. 45 (3), 277-282.

Runge, C.A., Martin, T.G., Possingham, H.P., Willis, S.G., Fuller, R.A., 2014. Conserving mobile species. Front. Ecol. Environ. 12, 395-402. http://dx.doi.org/10.1890/ 130237.

Rutz, C., Hays, G.C., 2009. New frontiers in biologging science. Biol. Lett. 5, 289-292. http://dx.doi.org/10.1098/rsbl.2009.0089.

Santos, A.J.B., Freire, E.M.X., Bellini, C., Corso, G., 2010. Body mass and the energy budget of gravid hawksbill turtles (Eretmochelys imbricata) during the nesting season. J. Herpetol. 44, 352-359. http://dx.doi.org/10.1670/08-287.1.

Sawyer, H., Kauffman, M.J., 2011. Stopover ecology of a migratory ungulate. J. Anim. Ecol. 80, 1078-1087.

Schofield, G., Hobson, V.J., Lilley, M.K.S., Katselidis, K.A., Bishop, C.M., Brown, P., Hays, G.C., 2010. Inter-annual variability in the home range of breeding turtles: implications for current and future conservation management. Biol. Conserv, 143, 722-730.

Schofield, G., Scott, R., Dimadi, A., Fossette, S., Katselidis, K.A., Koutsoubas, D., Lilley, M.K.S., Pantis, J.D., Karagouni, A.D., Hays, G.C., 2013. Evidence-based marine protected area planning for a highly mobile endangered marine vertebrate. Biol. Conserv. 161, 101-109. http://dx.doi.org/10.1016/j.biocon.2013.03.004.

Starbird, C.H., Hillis-Starr, Z., Harvey, J.T., Eckert, S.A., 1999. Internesting movements and behavior of hawksbill turtles (Eretmochelys imbricata) around Buck Island Reef National Monument, St. Croix, U.S. Virgin Islands. Chelonian Conserv. Biol. 3, 237-243.

Storch, S., 2003. The Behaviour of Immature and Female Hawksbill Turtles (Eretmochelys imbricata) at Sea ( $\mathrm{PhD}$ dissertation). Christian-Albrechts-Universität, Kiel.

Sumner, M.D., 2016. trip: Tools for the Analysis of Animal Track Data. R Package Version 1.5.0.

Troëng, S., H Dutton, P., Evans, D., 2005a. Migration of hawksbill turtles Eretmochelys imbricata from Tortuguero, Costa Rica. Ecography 28 (3), 394-402.

Troëng, S., Evans, D.R., Harrison, E., Lagueux, C.J., 2005b. Migration of green turtles Chelonia mydas from Tortuguero, Costa Rica. Mar. Biol. 148 (2), 435-447.

Van Dam, R.P., Diez, C.F., 1996. Diving behavior of immature hawksbills (Eretmochelys imbricata) in a Caribbean cliff-wall habitat. Mar. Biol. 127 (1), 171-178. http://dx. doi.org/10.1007/BF00993657.

Van Dam, R.P., Diez, C.E., 1997. Diving behavior of immature hawksbill turtles (Eretmochelys imbricata) in a Caribbean reef habitat. Coral Reefs 16, 133-138.

Van Dam, R.P., Diez, C.E., 1998. Home range of immature hawksbill turtles (Eretmochelys imbricata (Linnaeus)) at two Caribbean islands. J. Exp. Mar. Biol. Ecol. 220 (1), 15-24. http://dx.doi.org/10.1016/S0022-0981(97)00080-4.

Van Dam, R.P., Diez, C.E., Balazs, G.H., Colón, L.A.C., McMillan, W.O., Schroeder, B., 2008. Sex-specific migration patterns of hawksbill turtles breeding at Mona Island, Puerto Rico. Endanger. Species Res. 4 (1-2), 85-94.

Walcott, J., Eckert, S., Horrocks, J.A., 2012. Tracking hawksbillsea turtles (Eretmochelys imbricata) during inter-nestingintervals around Barbados. Mar. Biol. 159, 927-938.

Walcott, J., Eckert, S., Horrocks, J.A., 2013. Diving behaviour of hawksbill turtles during the inter-nesting interval: strategies to conserve energy. J. Exp. Mar. Biol. Ecol. 448, 171-178. http://dx.doi.org/10.1016/j.jembe.2013.07.007.

Whiting, S.D., Hartley, S., Lalara, S., White, D., Bara, T., Maminyamunja, C., Wurramarrba, L., 2006. Hawksbill turtle tracking as part of initial sea turtle research and conservation at Groote Eylandt, Northern Australia. Mar. Turt. Newsl. 114, 14-15.

Worton, B.J., 1989, February. Kernel methods for estimating the utilization distribution in home- range studies. Ecology 70 (1), 164-168. http://dx.doi.org/10.2307/ 1938423.

Zbinden, J., Aebischer, A., Margaritoulis, D., Arlettaz, R., 2007. Insights into the management of sea turtle internesting area through satellite telemetry. In: Biological Conservation. 137(1). Elsevier, Barking, UK, pp. 157-162. http://dx.doi.org/10. 1016/j.biocon.2007.01.022.

Zermelo, E., 1931. Uber das Navigationsproblem bei ruhender oder veranderlicher Windverteilung. Z. Angew. Math. Mech. 11, 114-124. 